\title{
Idrætshistorie - hvordan? \\ Generelle metodiske og teoretiske problemstillinger
}

\author{
af Jørn Hansen
}

Lad os forestille os, at vi vil skrive en „idrætshistorie“. Hvordan ville vi gribe dette an?

- Ja, først må vi jo se, hvilket materiale der findes; hvilke fremstillinger og hvilke kilder kan vi anvende til vores formål.

- Nej, først må vi overveje, hvilken fremgangsmåde, der skal anvendes. Hvilket historiesyn fremstillingen skal skrives ud fra. Hvad meningen skal være med en „idrætshistorie". Kilder taler jo ikke af sig selv, de skal „,spørges“; og de svarer forskelligt alt efter, hvorledes der bliver spurgt.

- Åh, hold nu op med det pjat, du ved jo godt, at vi normalt har en idé og så forsøger vi at finde materiale, der kan vise om vores idé er holdbar eller ej.

- Ja, det er der noget om, men har du overvejet, hvorfra du har din idé om, hvorledes en ,idrætshistorie“" skal se ud?

\section{2}

Det vil altid være kunstigt at formulere sig om generelle teoretiske og metodiske problemstillinger, ikke desto mindre er det ofte nødvendigt, ovenstående lille eksempel skulle gerne vise dette.

Inden for historiestudiet og historieforskningen i Danmark har der i al fald siden Erslevs tid været diskuteret metodiske og teoretiske problemstillinger. Nogle gange har diskussionerne været afdæmpede, andre gange har de været så voldsomme, at resultatet næsten er blevet et skift fra én måde at beskæftige sig med historie på til en anden/,ny“ " måde at beskæftige sig med historie på.

De sidste voldsomme teoretiske og metodiske diskussioner inden for historieforskningens område påbegyndtes i slutningen af 1960'erne og varede ved op gennem 70'erne. De er vel næppe afsluttede nu, men føres nu betydeligt mere afdæmpede.

Resultatet er blevet, at man i dag inden for historieforskningens og historieskrivningens område i højere grad vægter økonomiske og sociale 
emner. Tidligere var det den politiske historieskrivning, der havde første prioritet.

Således fremstår situationen $i$ dag som et resultat af de metodiske og teoretiske diskussioner fra slutningen af 60'erne og begyndelsen af 70'erne. Dengang diskussionerne blev ført tog det først og fremmest form som en voldsom kritik af den politiske historieskrivning som værende for utilstrækkelig (økonomien betyder meget mere end politik); for irrelevant (hvorfor høre om konger, præsidenter og generaler, når det er masserne, der skaber historien). Vi vil have historie for folket var et af slagordene.

Målet med de teoretiske og metodiske diskussioner var således at få inddraget materiale, der kunne belyse menneskenes levevilkår og daglige liv. Vi nærmer os således gennem udviklingen inden for selve historieforskningen og historieskrivningen idrætshistoriens emneområde. Det burde historieforskningen og historieskrivningen i al fald gøre ud fra de overvejelser, der lå til grund for de metodiske og teoretiske diskussioner.

Før jeg går over til at beskæftige mig med metodiske og teoretiske problemer ved at skrive idrætshistorie kunne det derfor være på sin plads at se nærmere på, hvilken rolle idrættens og sportens område tildeles $i$ en næsten autoriseret dansk socialhistorie. Jeg tænker her på ,Dansk Socialhistorie bd. 1-7" som Gyldendal og Statens Humanistiske Forskningsråd i fællesskab har udgivet i slutningen af 70'erne og begyndelsen af dette årti.

3

Jeg har set nærmere på „Dansk Socialhistorie bd. 6 og 7“, der omhandler perioden fra 1. verdenskrig til i dag. En periode, hvor idrætten og sporten virkelig kommer til at spille en stor rolle for social menneskelig adfærd.

Forfatterne Svend Aage Hansen og Ingrid Henriksens definition af socialhistorie synes da også at kunne indbefatte sportens og idrættens område. De skriver:

„Socialhistorie er historien om samtlige befolkningsgruppers levevilkår og deres relationer til og reaktioner over for hinanden, historien om deres samarbejde og deres kampe“. (bd. 6 s. 12).

Jeg havde selvfølgelig ikke forestillet mig, at disse kampe var Fremad Amager mod ,,de fine“ "fra KB eller AIA mod ,,de fine“ fra AGF, selv om disse „,kampe" både udtrykker et samarbejde og en kamp mellem forskellige befolkningsgrupper.

Alligevel forundres jeg over den måde sporten og idrætten behandles på.

Først opdager man, at de to forfattere næsten udelukkende skriver økonomisk socialhistorie og som sådan indsnævrer deres egen definition. 
Derefter opdager man, at hverken idrættens eller sportens rolle og betydning omtales. I bind 7 svinger forfatterne sig op til at skrive et afsnit på 6 sider om „,Masseforbrug og fritidsindustri“", der ud over parcelhuse, TV og charterrejser blot omtaler socialforskningsinstituttets fritidsundersøgelser fra 1964 og 1975.

Jeg skriver ikke dette alene for at moralisere på idrætshistoriens vegne; men lige så meget fordi jeg mener, at det er de to forfatteres forståelse af socialhistorie som økonomisk statistisk levevilkårsundersøgelser, der stiller idrætten og sporten udenfor. Ved udelukkende at anvende denne metode overses ,,det levede liv“", folkets aktiviteter og kulturelle udfoldelse i dagligdagen.

Meget længere i retning af ,,god“ socialhistorie når Søren Mørch i sin ,Den ny Danmarkshistorie 1880-1960“. I dette værk tildeles kulturlivets, privatlivets og moralens betydning for danskerne en afgørende rolle. Alene kvantitativt gør disse emner det ud for over $1 / 3$ af bogen.

\section{4}

Hvilke teoretiske og metodiske problemer rejser der sig, når man skal skrive idrætshistorie?

Vi ved, at der er forskellige måder at skrive historie på; det samme gør sig gældende for idrætshistorie. Umiddelbart forekommer det mig, at der er mindst 4 forskellige måder at forske i og skrive idrætshistorie på:

1. Traditionelt har en indfaldsvinkel til idrætshistoriske studier for mange været en diskussion af sportens placering og rolle i ,,det moderne“" samfund. De skrifter og artikler, der er kommet ud af en sådan indfaldsvinkel, har som regel anvendt en kritisk sociologisk metode; har bevæget sig på et højt abstraktionsniveau og har ofte fældet absolutte domme. Som eksempel kan nævnes frankfurterskolens sportskritik.

2. Ovennævnte indfaldsvinkel er på en mere frugtbar måde blevet udvidet med en historisk kritisk sociologisk analyse. Det historiske har bestået i en diskussion af sportens (legemskulturens) rolle i forskellige historiske samfund: det antikke, det feudale og det kapitalistiske/industrielle samfund. Sporten (legemskulturen) bestemmes $\mathrm{i}$ forhold til arbejdsdelingens udvikling. Fra at være en del af arbejdet (f.eks. krigernes øvelser $\mathrm{i}$ antikken) til at blive et fritidsfænomen. En undersøgelse, der ligeledes befinder sig på et højt abstraktionsniveau, anvender idealtypebestemmelser og kun kan have gyldighed på det almene/generelle plan. Et eksempel er Karin Rittners „Sport und Arbeitsteilung. Zur sozialen Funktion und Bedeutung des Sports". 
Mere traditionelt historiske er de sidste to former for idrætshistorie, jeg vil omtale. Den store idrætshistorie, syntesen og detailstudiet, analysen.

3. Ligesom der skrives Danmarkshistorie, skrives der ,Dansk Idræts Historie gennem 200 år" . Det er hovedbegivenhederne og det er de lange linier, der trækkes frem i en sådan idrætshistorie. Vi befinder os på synteseplanet. Vi bliver præsenteret for idrættens store historie, ligesom vi i de fleste Danmarkshistorier bliver præsenteret for de store begivenheder. Et eksempel på en sådan idrætshistorisk fremstilling er Ove Korsgaards ,Kampen om kroppen. Dansk Idræts historie gennem 200 år" .

4. Detailstudier. Idræt og sport er mange ting. Enkelte sportsgrenes historie kan undersøges og beskrives. Organisationernes historie kan beskrives. Idrættens historie kan fremstilles i lokalhistorisk regi, osv.

Hvor de tre første måder at lave idrætshistorie på hver for sig sætter en bestemt fremgangsmåde er detailstudierne for forskelligartede til, at vi kan operere med én bestemt fremgangsmåde. Til at beskrive én idrætsorganisations historie vil fremgangsmåden være en anden, end hvis idrættens kulturelle betydning i et lokalmiljø skal beskrives.

En detailstudie er Mats Hellspongs ,Boxningssporten i Sverige. En studie i idrottens kulturmiljö“. Fremgangsmåden er etnologisk kulturhistorisk og som sådan (selvfølgelig) ganske anderledes end fremgangsmåden i de tre først nævnte idrætshistorier. Vi har her et eksempel på forskellen mellem den lille historie (Hellspong) og den store historie (Rittner og Korsgaard).

$\mathrm{Nu}$ skulle denne artikel handle om generelle metodiske og teoretiske problemstillinger, og indtil nu har jeg præsenteret $i$ al fald fire forskellige måder at studere og skrive idrætshistorie på. Altså præsenteret flere forskellige metoder.

Det har jeg ikke gjort for at forvirre, men for at belægge det generelle udsagn, at: DER FINDES INGEN SPECIFIK IDRETSHISTORISK METODE. Ligesåvel som den historiske metode heller ikke eksisterer.

Det emne, der skal undersøges, og formålet med undersøgelsen bestemmer, hvilken fremgangsmåde der anvendes. Genstanden bestemmer metoden, som det hedder $\mathrm{i}$ videnskabsteoretiske termer.

I det foregående skulle jeg gerne have vist, at der dels findes flere forskellige formål med idrætshistoriske undersøgelser og dels findes et utal af emner inden for idrætshistorien. På det teoretiske plan er det derfor nærliggende at lægge op til en diskussion af:

a) formålet med en idrætshistorisk forening, og

b) en diskussion af idrætshistoriens genstandsområde.

Diskussioner der, såvidt jeg kan se af den foreløbige indholdsfortegnelse til årbogen, tages hul på i andre artikler.

Jeg vil ikke $\mathrm{i}$ den her sammenhæng udbrede mig nærmere om disse 
diskussionspunkter. Generelt tror jeg, at vi p.t. tjener ,,sagen“ bedst ved at forstå idrætshistorien så bredt som muligt og forholde os fordomsfrit til forskellige metoder og indfaldsvinkler. I stedet vil jeg bidrage til diskussionerne ved at give mit bud på, hvordan idrætshistorie bør studeres, idet jeg samtidig forsøger at rejse en række problemer, der er forbundet med at skrive ,god" idrætshistorie.

\section{5}

Formålet med at studere og skrive idrætshistorie er i første omgang at få idrætshistorien ind i varmen. Men idrætshistorie bør på langt sigt ikke studeres for idrættens skyld alene. Idrætshistorie bør ikke blive en disciplin på linie med religionshistorie, kunsthistorie eller idéhistorie. Idrætshistorie bør efter min opfattelse studeres for historieskrivningens skyld. Idrætshistorie bor bidrage til, at historieskrivningen kan behandle menneskets ,totale livssituation". Til at historieskrivningen kan blive god socialhistorie.

I begyndelsen af 1970'erne skete der et kolossalt opsving i interessen for arbejderbevægelsens historie. Arbejderbevægelsens historie skulle gøres synlig. Dannelsen af Selskabet til Forskning i Arbejderbevægelsens Historie (SFAH) i 1970 er blandt andet et udtryk for dette. Der udkom mange bøger om arbejderbevægelsens historie. Til socialdemokraternes „,En bygning vi rejser " og kommunisternes ,Det knager i samfundets fuger og bånd“" føjedes andre venstrefløjspartiers og personers tolkninger af de samme begivenheder, f.eks. ,Lad falde, hvad ikke kan stå“.

Fagbevægelsens historie/historier blev skrevet. De ,glemte“ arbejdskampe blev gravet frem af historikerne. De ledende personer fik tildelt heltenes eller skurkenes rolle. Men de, det drejede sig om, arbejderne, mænd, kvinder og børn fik ingen historie. Også arbejderbevægelsens historie blev historie set fra oven, som George Haupt en af arbejderbevægelsens store historikere skrev i en artikel umiddelbart før sin død i 1978. I artiklen, der hedder „Hvorfor en arbejderbevægelsens historie" udvikler Haupt slutteligen den forskningsstrategi, der siden har bevæget mange historikere over i retning mod socialhistorisk historieskrivning:

„For at blive i stand til at gå dybere end til den overfladiske historie, er det nødvendigt at gå nye veje, som delvist påbegyndt af socialvidenskaberne. „Opgaven er uomtvistelig vanskelig“, som Michel Perrot (hvis egne værker giver os et eksempel på måden at overvinde vanskelighederne på) har fastslået, fordi historie er ,en opdelt disciplin, omskiftelig, splittet mellem mange forskellige sprog, udsat for forskellige metoder, pint af så mange spørgsmål, involveret $\mathrm{i}$ den diabolske virkelighedssø- 
gen, som hjemsøger den og flygter fra den". Konfrontationen mellem traditionel historie og en arbejderklassehistorie, som er resolut socialt orienteret, er ikke simpelt hen et sterilt akademisk skænderi eller en abstrakt metodologisk debat." (Årbog for Arbejderbevægelsens historie 1979 s. 25. Michel Perrot er en fransk socialhistoriker, der især har skrevet om arbejderbevægelsen i slutning af forrige århundrede).

Med lidt forsigtighed mener jeg, at mange af de krav, som Haupt rejser i sin artikel, kan overføres til målet med at beskæftige sig med idrætshistorien.

Idrætshistorie bør ikke være ,historie fra oven". Vi skal beskæftige os med idrætshistorie som en social og kulturel foreteelse i dagligdagen. Vi skal efterspore spændingsfeltet mellem historien og idrætshistorien. Er idrætshistorien altid en harmonisk integreret del af samfundshistorien? Vi skal påvise, hvilke elementer $\mathrm{i}$ idrætshistorien der er systemtilpassende, og hvilke der er frigørende. Hvilke befolkningsgrupper knytter de systemtilpassende elementer sig til, hvilke befolkningsgrupper knytter de frigørende elementer sig til.

For eksempel står der $\mathrm{i}$ jyske husmandsforeningers tidsskrift ,Husmandshjemmet" i 1930'rne, at gymnastik er godt for en jysk husmand, men sport det fører direkte til cigaretrygning, til arbejdsløshed og til usund livsførelse. (se Claus Bjørn ,Idrætshistorie i Danmark“ i „Rapport fra Idrætshistorisk seminar"s. 16).

Ligesåvel som arbejderbevægelsens historie i Haupts udlægning bliver til brydningsfyldt socialhistorie, bliver idrætshistorie i „,min“ udgave til brydningsfyldt socialhistorie. Således bliver såvel arbejderbevægelsens historie som idrætshistorien indoptaget $i$ totalhistorien. Bliver til dele, der indgår $i$ den totalhistoriske fremstilling, som alle så gerne vil skrive, men har så svært ved at skrive.

Et godt eksempel på en „,totalhistorisk“ fremstilling er Eric Hopkins „,A Social History of the English Working Class 1815-1945“. I denne fremstilling dækkes alle sider af arbejderklassens liv. Arbejdsliv, hjemmeliv, opdragelse, skolegang, fritidsliv og sport fremstilles sammen med levevilkårene og den politiske og økonomiske historie.

\section{6}

Hvorfor er det så vanskeligt at skrive en totalhistorisk fremstilling, og hvilke problemer rejser der sig i den forbindelse med en idrætshistorie, der skal være socialhistorisk.

Problemet er at give en beskrivelse af „den totale livssituation" som samtidig er historisk. 
Historien bevæger sig. Men de emner/genstande, der er en del af historien, bevæger sig ikke med samme hast og rytme. De elementer, der tilsammen udgør historien, kan godt have en forskellig historie; tilnærmelsesvis en egen historie. Alligevel bindes de sammen og drives fremad af ",udviklingen“ in fact økonomien/de materielle vilkår som sidste årsag .

Formuleret på en anden måde er problemet, hvorledes undgår man, at beskrivelsen af den totale livssituation bliver statisk. Bliver til en beskrivelse, hvor historiens dynamik er fjernet.

En lille figur kan måske eksemplificere:

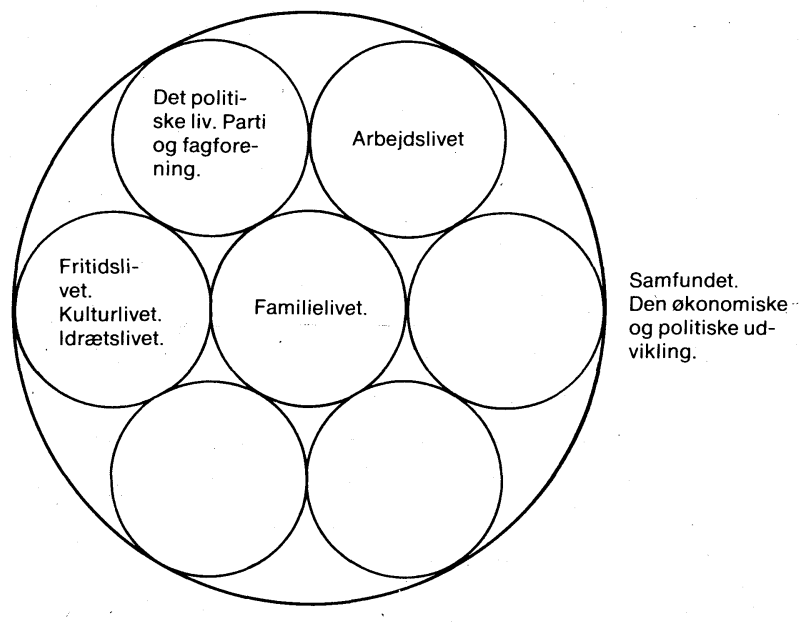

Den store cirkel er samfundet, dets økonomi og politik, det der almindeligvis opfattes som historiebevægende. De små cirkler, der skal tænkes som dele af den store cirkel, er elementer/emner, der indgår i den totale livssituation. (At de små cirkler er lige store er ikke udtryk for nogen vægtning).

Familielivet er præget af samfundets historie. Idrætslivet er præget af samfundets historie. Men familien og idrætten har også sin egen historie, sin egen tradition og undergår ikke altid ændringer i samme hast og på samme måde som den økonomiske og politiske historie. Focuserer man således på bestemte sider af den totale livssituation, kan man risikere at fiksere historien.

Et anskueliggørende eksempel, der måske også kan vise sig at blive et problem for idrætshistorie, er en entydig focusering på ,,det almindelige menneskes" stille liv. Beskrivelsen af de stille stunder med aftenkaffen foran TV i familiens skød, af værtshuslivets og friluftslivets kammeratskab, kollektivitet og drømme kan nemt blive historieløs. 
Eksemplet med det almindelige menneskes stille liv kan også anvendes til at diskutere, hvad alternativet skal være til „,historie fra oven“.

Mange historikere har taget den konsekvens, at det gælder om at vende bøtten. Historien bør ses „,fra neden“.

Indfaldsvinklen til historieskrivningen og historiestudiet blev i første omgang de almindelige menneskers levevilkår. Dernæst i forsøget på at få pustet liv i de almindelige mennesker udvidedes dette som sagt til at omfatte hele livssituationen; de almindelige menneskers liv i hverdag og fest. I forlængelse heraf fulgte ofte en tendens til at heroisere det ,,almindelige " liv. Dagligdagen var ikke blot en forbandelse, der var megen glæde, der var megen idræt, der var megen fest.

Fascinationen over livet ved Solkongens hof erstattes af fascinationen ved smed Petersens liv på arbejdet, i familien og på sportspladsen. Studierne bliver gjort lokalhistoriske. Dette er måske i orden, initiativerne er i al fald velmente. Men man skal være klar over, hvad man gør. Man skriver ikke totalhistorie. Man beskæftiger sig med den såkaldte lille historie.

Ovennævnte fremgangsmåde er efterhånden meget populær og ofte forsøgt anvendt. Men denne fremgangsmåde rummer et stort problem: hvorledes forbindes den lille historie med den store historie. Den store historie, der anskueliggør samfundenes ændringer. Og som et næste problem, hvorledes anskueliggøres, at også den store historie er menneskeskabt, er udtryk for en kollektiv menneskelig proces. Hvorledes undgås, at den store historie ikke reduceres til en ydre foreteelse, der enten blot passerer forbi den lille historie eller griber direkte forstyrrende ind i den lille historie. Vel er det svært, men hvis denne kobling ikke forsøges, risikerer vi, at den lille historie - man kan også sige idrættens lille historie - både bliver historieløs og til folklore.

\section{8}

Koblingen af den lille og den store historie kompliceres yderligere af, at der anvendes forskellige fremgangsmåder/metoder i studiet af den lille og den store historie. Den store historie har efterladt sig mange spor; som regel findes den allerede beskrevet i fremstillinger. Det er således også idrættens „store historie“, der har efterladt sig flest spor. Idrætsorganisationernes historie, idrætsbetænkninger, idrætspolitiske vedtagelser, olympiadernes historie $\mathrm{mm}$.

Problemet med den lille historie er, at den ikke har gjort sig synderligt bemærket. Der eksisterer ikke den rigdom af kilder, som historikerne 
traditionelt kan ty til. Den lille histories kilder er ofte forsvundne i historiens støv - dette viser om ikke andet, hvorledes også den lille historie er historisk.

Da Nils Malmros skulle lave „,Kundskabets træ" var det eneste hjem, der skulle rekonstrueres „Klisters“ (arbejderpigens) teaktræs barndomshjem. De bedrestilledes villaer eksisterede stadig i samme tidløse stil som i 50'erne.

Ydermere forstørres problemet med at beskæftige sig med den lille historie ved at emnet ,,det levede liv“ kræver anvendelsen af såkaldte utraditionelle metoder. Jeg har tidligere nævnt en etnologisk kulturhistorisk fremgangsmåde. Dertil kommer anvendelsen af socialisationsteoretiske metoder; hvilken bevidsthed dannes i hverdagen, på arbejdet, i familien, i fritiden.

Materiale der kan anvendes til at studere den lille historie er erindringer, interviews, folkemindesamlinger, fotos, sange og andre kulturhistoriske efterladenskaber. Dertil kommer levevilkårsundersøgelser, tidsforbrugs og døgnrytmeundersøgelser. Til idrætshistoriske studier kan føjes udbredelsen af idrætsfaciliteter, deres indretning og anvendelse. Idrætsklædedragter, sportsaggregater, idrætsfaner $\mathrm{mm}$.

Lad mig sammenfatte mit bud på mål med at studere idrætshistorie:

- Idrætshistorie bør være en del af den humanistiske disciplin historie. Histories og humanioras erkendelsesledende interesse (dvs. målet med at beskæftige sig hermed) er menneskets frigørelse. Idrætshistoriens mål bør være frigørelsen af kroppen, ophævelsen af dualismen mellem krop og ånd.

- For at understrege historien som en menneskeskabt proces bør idrætshistorien og historien være socialhistorisk. Det bør undersøges hvilken idrætshistorie, der er knyttet til bestemte klasser eller grupper.

- Idrætshistorie bør ikke på langt sigt stå alene, men være medvirkende til at afdække „,den totale livssituation“.

- Det bør efterstræbes at efterspore spændingsfelter i såvel selve idrætshistorien som i idrætshistoriens relationer til den historiske virkelighed i øvrigt.

9

Årbogens redaktionsgruppe havde bedt mig skrive om generelle metodiske og teoretiske problemstillinger herunder begrebsapparatet. Jeg ved ikke, om det er en artikel af denne art, redaktionsgruppen havde forventet. Der kan bestemt fremdrages andre relevante metodiske og teoretiske problemstillinger ved at skrive idrætshistorie, end jeg har gjort. Jeg har koncentreret mig om „Idrætshistorie hvordan?" i et forsøg på bedre at anskueliggøre de metodiske og teoretiske problemstillinger.

Begrebsapparatet har jeg ikke beskæftiget mig med. Det er bevidst. Udformningen af et generelt begrebsapparat for en idrætshistorie vil være 
lige så forkert som anvendelsen af én generel idrætshistorisk metode til studiet af hele idrætshistoriens genstandsområde. Behovet for at anvende et eller flere begrebsapparater vil vise sig i det øjeblik, man giver sig af med at studere et specifikt idrætshistorisk emne og vil som sådan følge den metode, der anvendes. Generelt kan man blot sige, det gælder om at gøre sig sit begrebsapparat klart både for sig selv og for læserne i fremstillingen. Dette kan føre til relevante begrebslige afklaringer.

Ét eksempel herpå er Ove Korsgaards anvendelse af begreberne legemskultur og sport. Et andet eksempel er Torben Jakobsens anvendelse af begreberne legemskultur, sport og idræt i afhandlingen ,Legemskultur i mellemkrigstiden". Korsgaard og Jakobsen anvender ikke begreberne helt på samme måde. Til studiet af legemskulturen i mellemkrigstidens Danmark finder Torben Jakobsen det nødvendigt at anvende både betegnelserne sport og idræt for at påvise, hvorledes idrætten (den folkelige på landet udøvede idræt) nærmer sig sporten (den i byerne dominerende konkurrencesport). Denne fremgangsmåde hos Torben Jakobsen skyldes ikke, at han er utilfreds med Korsgaards begrebsapparat, men at han finder, at det emne, han vil studere, kræver yderligere begrebslig afklaring.

Hvorvidt vi så i studiet af idrætshistorien kan få så stor indsigt og lavet så mange fremstillinger, at begreberne - nøgleordene - med tiden vil være selvfølgelige for os, er en anden sag.

\section{0}

\section{Litteraturliste:}

- Oluf Bertolt, Ernst Christiansen og Poul Hansen: ,En bygning vi rejser" Fremad, Kbh 1954.

- Georges Haupt: „Hvorfor en arbejderbevægelsens historie?“ i „Årbog for Arbejderbevægelsens Historie 1979".

- Jürgen Habermas: „Soziologische Notizen zum Verhältnis von Arbeit und Freizeit". 1956.

- Mats Hellspong: „Boxningssporten i Sverige. En studie i idrottens kulturmiljö“. Nordiska museets handlingar 99, 1982.

- Svend Aage Hansen og Ingrid Henriksen: „Dansk Socialhistorie bd. 6 og 7“. Gyldendal, Kbh. 1980.

- Eric Hopkins: „A Social History of the English Working Classes 1815-1945“. Edward Arnold London 1979.

- Torben Jakobsen: „Legemskultur i mellemkrigstiden. En analyse af den folkelige idræts ideologi og praksis i perioden 1919-40 i Danmark med særligt henblik på splittelsen inden for denne i 1929/30". Specialeafhandling Historisk Institut Århus 1982.

- Knud Knudsen: „Socialhistorie - socialistisk historie. En præsentation af 1970'ernes engelske diskussion om ,,socialistisk historie“. En introduktion til den marxistiske 
historietradition i England. Og nogle synspunkter og betragtninger om begrebet ,,socialhistorie“. AUC 1982 upubliceret.

- Ove Korsgaard: „Kampen om kroppen. Dansk Idræts historie gennem 200 år“. Gyldendal, Kbh. 1982.

- Søren Mørch: „Den ny Danmarks Historie 1880-1960“. Gyldendal 1982.

- Ib Nørlund: ,,Det knager i samfundets fuger og bånd“". Tiden, uden årstal.

- ,Rapport fra idrætshistorisk seminar den 7.-8. oktober 1983 på Danmarks Højskole for Legemsøvelser".

- Karin Rittner: „Sport und Arbeitsteilung. Zur sozialen Funktion und Bedeutung des Sports “. Limpert, Bad Homburg 1976.

- Forbundet Socialisterne: ,Lad falde, hvad ikke kan stå. Dansk arbejderbevægelses historie". Aurora 1976. 


\section{Idsping i Thensen fra 30 Pods llojio.}

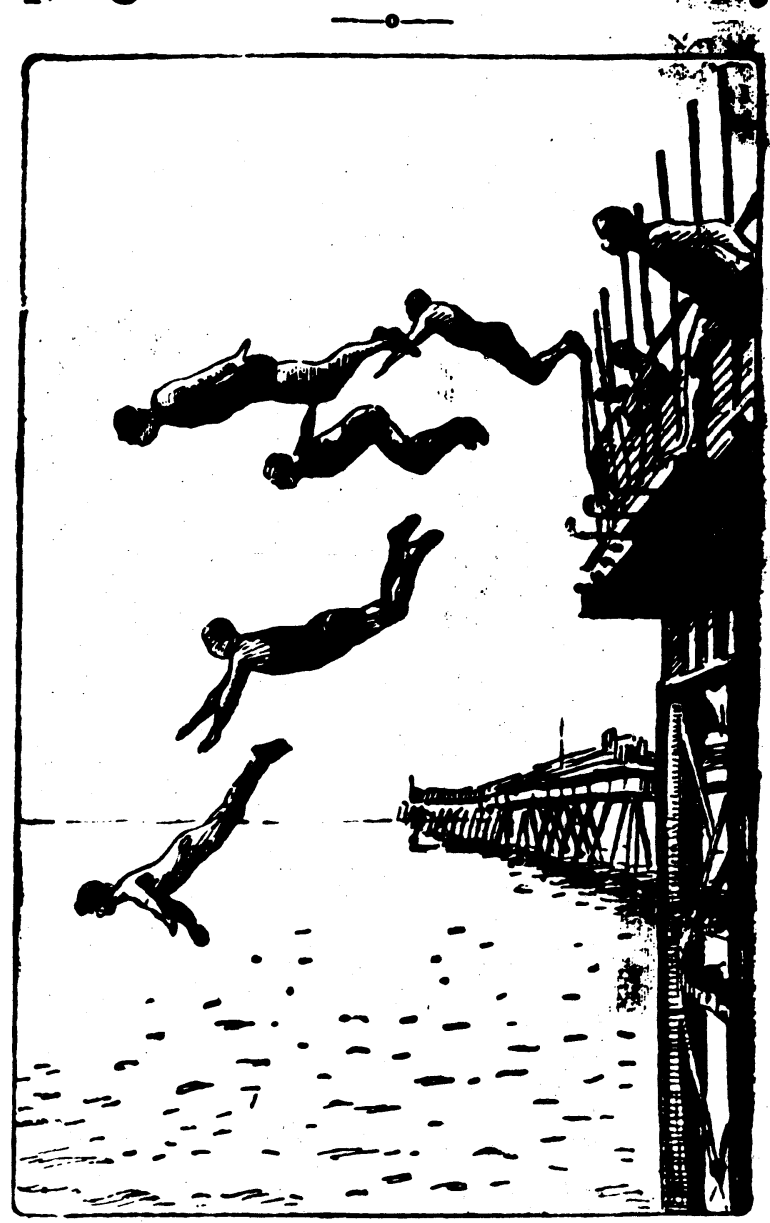

Sommeren 1905 bragte en række tegninger fra svømmelivet i England, især centreret omkring Themsen og den engelske kanal. Det skal nok især ses $i$ sammenhæng med den store interesse, der var for en kanalsvømningskonkurrence til minde om kaptajn Webb, der i 1875 svømmede fra Dover til Calais. Ovenstående tegnings billedtekst fra den 15. september nævner således miss (Annette) Kellermann (fra Australien), der netop var en kendt „,kanalsvømmer". 